\title{
THE APPROACH OF ISLAMIC STUDIES IN MAPPINGRICHARD C. MARTIN
}

\author{
Nur Solikin \\ Faculty of Sharia and Postgraduate UIN Kiai Haji Achmad Siddiq Jember \\ nursolikin.iainjember@gmail.com
}

\begin{abstract}
Abstrak
Kajian ini berfokus pada pemetaan pendekatan studi Islam dalam salah satu karya Richard C. Martin yang disunting berjudul Approaches to Islam in Religious Studies. Penelitian ini mengambil bentuk deskriptif-analitis yang dimulai dengan mengungkap latar belakang penulisan hingga evolusi sejarah studi agama. Melalui penelitian ini, beberapa kesimpulan yang dapat dikemukakan terkait dengan kecemasan akademik Martin, yang diakuinya dilatarbelakangi oleh kelemahan antara pendekatan teologis yang mempertahankan pemahaman normatif agama, dan sudut pandang sejarah agama yang menekankan pada deskripsi analitis dan membutuhkan jarak bagi para penelitinya. Sementara terkait dengan evolusi studi sejarah agama, ia menilai perkembangan studi independen setelah studi sejarah, antropologi, sosiologi, teologi dan studi timur, dan oleh karena itu, perkembangan studi tersebut cukup berpengaruh dalam cara sejarawan agama bekerja. Pengembangan lebih lanjut dianggap perlu untuk memisahkan studi agama dari disiplin lain.
\end{abstract}

Kata Kunci: Pendekatan, Studi Islam, Richard C. Martin

\begin{abstract}
This study focuses on the mapping of the Islamic studies approach in one of Richard C. Martin's edited works entitled Approaches to Islam in Religious Studies. This study takes adescriptiveanalytical form which begins by revealing the background of writing to the historical evolution of religious studies. Through this study, several conclusions that can bepresented are related to Martin's academic anxiety, which he admits is motivated by a weakness between the theological approach which maintains a normative understanding of religions, and the history of religion point of view which emphasizes analytical descriptions and requires distance for the researchers.While related to the evolution of the study of the history of religion, he assessed the development of independent studies after historical studies, anthropology, sociology, theology and the study of the east, and therefore, developments inthese studies were quite influential in the way historians of religions worked. further developments are deemed necessary to separate religious studies from other disciplines.
\end{abstract}

Keywords: Approach, Islamic Studies, Richard C. Martin 


\section{Nur Solikin}

\section{Introduction}

The Islamic studies approach is an interesting discourse in the discourse of Islamic sciences. This is not only due to a direct relationship with divine values alone, but also to the existence of a relationship with the reality of religious life, and hisstudies no longer question the area of Islamic studies, as revealed by Sjoerd van Koningsveld, Islamic studies in the Netherlands are no longer a problem. about the area of Islamic study because the Orientalists thought it was final. The emphasis of their study is on the issue of approach to be used in studying Islam. ${ }^{1}$ Thisis due to the growing awareness of the importance of various scientific approaches in the field of Islamic Studies and attention to problems resulting from various approaches such as philological, historical, anthropological and sociological approachesto religious data. ${ }^{2}$

Responding to these demands, the name Richard C. Martin through his edited work, Approaches to Islam in Religious Studies deserves to be placed as a scientist who has a concern for the above demands, inaddition to the names of other scientists such

1 Jacques Wandenburg, "Islamic Studies in the Netherlands", in Nanji Azim (ed)., Map of Islamic Orientalism Studies and New Directions of Islamic Studies in the West, (Bantul: Fajar Pustaka Baru, 2003), p. 114

2 M. Amin Abdullah, "Foreword" in, Richard C. Martin, Approaches to Islamic Studies in Religious Studies, trans. Zakiyudin Baidhawi (Surakarta: Muhammadiyah University Press, 2001), p. iv as Mohammer Arkoun through his writing, Tarikhiyatu al-Fikr al-Araby al-Islamy and Nasr Hamid Abu Zaid who have presented the paper, Naqd al-Khitab al-Diniy. ${ }^{3}$

The history of religion viewpoint emphasizes a scientifically analytical description of other religions and requires some distance for researchers. Another factor is the failure of religious studies to be transformed into a special discipline despite the emergence of religious departments or religious studies in various universities in North America which have a myriad of dataon textual expression and human religious behavior.

Based on his academic anxiety, this paper was presented as an effort to bring and lift the study of Islamic studies out of its historical-cultural traps and traps to the major currents of religious science that developed since the 19th century with its various methodological tools, as well as presenting various an approach that can bridge the methodological gap between Islamic Studies and Religionswissenschaft.

The researcher used the descriptiveanalytical methods which is one of the procedures to collect and analyze data. This study begins by revealing the background of writing to the historical evolution of religious studies.

${ }^{3}$ M. Amin Abdullah, Islamic Studies in Higher Education: Integrative-Interconnective Approach, (Yogyakarta: Pustaka Pelajar, 2006), pp. 187 


\section{Research Results and Discussion}

\section{Richard C. Martin and his academic restlessness.}

In one of the books he edited, Rethinking Islamic Studies from Orientalism to Cosmopolitanism, Richard C. Martin is listed as a professor in the field of Islamic Studies and History of Religions at Emory University, and is also listed as a former president at the American Research Center in Egypt who fills the day. -the day by writing and teaching a number of subjects such as, Islamic Thought, Religion, Social Conflict, Violence, Islam and Secularism. Among theworks he has produced, such as Defenders of Reason in Islam: Mu'tazilism from Medieval School to Modern Symbol, which was written with Mark R. Woodward and Dwi Atmaja in1997. In 2004, Richard C. Martin also becameeditor of writing encyclopedias of Islam andthe Muslim World. Then in 2010, together with Carl W. Ernst is the editor of a collection of writings on the theme Rethinking Islamic Studies from Orientalism to Cosmopolitanism. Likewise, a collection of essays entitled, Approaches to Islam in Religious Studies, Richard C. Martin is also listed as the editor. ${ }^{4}$ These works, of course in addition to the numerous articles that have

\footnotetext{
${ }^{4}$ Carl W. Ernst and Richard C. Martin, Rethinking Islamic Studies from Orientalism to Cosmopolitanism (Columbia, University of South Carolina Press, 2010), p. 326
}

been published in various journals such as "Marriage, Love, and Sexuality in Islam: An Overview of Genres and Themes"in, Covenant Marriage in Comparative Perspective (William B. Eerdmans Publishing Company, 2005); "Familiar Idolatry and the Christian Case against Marriage"in, Authorizing Marriage? Canon, Tradition, and Critique inthe Blessing of Same-sex Unions (Princeton University Press, 2006), and" Conversion to Islam by Invitation: Proselytism and the Negotiation of Identity in Islam "in, Sharing the Book: Religious Perspectives on the Rights and Wrongs of Proselytism (Orbis Books, 1999). ${ }^{5}$

Especially for the last work above, Approaches to Islam in Religious Studies, as expressed by Charles J. Adam in his introduction, comes from a collection of writings presented at a symposium on Islam and the history of religions held at Arizona State University in January 1980, although in his assessment, This achievement exceeded the achievement targeted by the symposium because according to Adam he had gathered trained scholars in religious studies for the first time in North America who were specifically presented not only to discuss theproblem of methods and approaches to abstract Islamic studies but also to pay special attention to specific aspects of the Islamic

\footnotetext{
${ }^{5}$ http: / / cslr.law.emory.edu / people / person / na me / martin / . Accessed on, 01 September 2020.
} 


\section{Nur Solikin}

tradition and the use of various theoretical and methodological views of religious science to study the area of Islamic studies. ${ }^{6}$

In a different language, Amin Abdullah said that Richard C. Martin's edited work was full of methodological content directed at the author's efforts to bring and lift Islamic studies out of its historical-cultural traps andtraps into the realm of the mainstream of religious science that has developed since the century. 19th with its various methodological tools. On the other hand, according to AminAbdullah, such efforts are also expected to be able to bridge the methodological gapbetween Islamic Studies and Religions wissenschaft which is still being felt today. ${ }^{7}$ These two things are also the contribution of Richard C. Martin's work in the study of Islamic studies.

The above assessment can be traced by looking at academic anxiety - or rather the background of editing the book - which, according to Martin, is at least motivated by the traditional position of Islamic studies at North American universities in eastern and regional study programs which are considered to be in a strategic position. the problem because it has given birth to two

sub-fields from different points of view, and often even opens opportunities for conflict

${ }^{6}$ Charles J. Adam, "Foreword", in, Richard C. Martin, Approaches to Islam in Religious Studies (Tucson: Arizona State University Press), p. viii

${ }^{7}$ M. Amin Abdullah, "Foreword", p. iv between one another, namely, a theological point of view that maintains a normative understanding of other religions so that these religions must be judged by claims conventional Christian, while on the other hand, The history of religion point of view emphasizes a scientifically analytical description of other religions and requires some distance for researchers. ${ }^{8}$

Indeed, as has been written by M. Amin Abdullah, the point of view of religious studies which is based ontheological building can be characterized as follows. First, the tendency to prioritize one's own group is very strong; second, there is personal involvement and deep appreciationof the theological teachings that are believed to be true; and third, expressing feelings andthoughts by using the language of the actor (actor) not the observer (spectator). ${ }^{9}$ Theaccumulation of these three characteristics inan individual or a community contributes significantly to creating a community that tends to be exclusive, emotional and rigid, even prioritizing truth claims compared to honest and argumentative dialogue. ${ }^{10}$ In other writings, Amin Abdullah called it the "believer" approach - which was later

\footnotetext{
${ }^{8}$ Richard C. Martin, Approaches to Islam in Religious Studies (Temple: Arizona State UniversityPress), p. 1 ${ }_{9}^{9}$ M. Amin Abdullah, Religious Studies: Normativity or Historical (Yogyakarta: Student Library, 2011), pp. 14

${ }^{10}$ M. Amin Abdullah, Religious Studies: Normativity or Historical, P. 15
} 
contradicted by what he called the "historian" approach. ${ }^{11}$

This approach is diametrically opposed to a historical-critical approach which will actually help clear up the issue of human diversity. ${ }^{12}$ However, in Amin Abdullah's observation, this empirical approach sometimes goes far beyond the limits of his authority, such as examples of theories emerging from sociological and psychological approaches that have led to a projectionist viewpoint, namely a perspective that sees religion only as a phenomenon. social, so that it loses its sacredness, the sacredness of its normative fibers, ${ }^{13}$ In fact, making religion an object of study is included in cultural studiesas expressed by Atho Mudzhar does not mean that religion itself is a creation of human culture because religion is stillbelieved to be a revelation of God but the view is intended that the approach used in itis a research approach commonly used in research including cultural research for example. Thus, it does not eliminate the normativity aspect of religion even though

\footnotetext{
${ }^{11}$ M. Amin Abdullah, The philosophy of Kalam in the Postmodernism Era, (Yogyakarta: Pustaka Pelajar, 2009), pp. 25

${ }^{12}$ M. Amin Abdullah, Religious Studies., P. 15

${ }^{13}$ M. Amin Abdullah, Religious Studies, P. 11
}

on the other hand it does not forget the historical-empirical dimension of religion. ${ }^{14}$

In Richard C. Martin's assessment, the two tendencies above, both theological and historical approaches are equally extreme, oneis called fideistic subjectivism and the other is called scientific objectivism by Martin. ${ }^{15}$ Fideistic subjectivism is a view that states that humans are basically born in a religious stateso that if they do not worship the true God, they will worship the gods they created themselves. This shows that humans are never religiously neutral, whereas what Martin calls scientific objectivism is aperspective that shows that an impartial andbiased critical mind will lead to the truth, therefore thinking right about religion requires eliminating all commitments andtaking a position. neutral. ${ }^{16}$

Another factor is the failure of religious studies to be transformed into a special discipline even though on the other hand there have been departments of religion or religious studies in various universities in North America that have a myriad of data on textual expression and human religious behavior, but still, religious

\footnotetext{
${ }^{14} \mathrm{M}$. Atho Mudzhar, Approaches to Islamic Studies in Theory and Practice (Yogyakarta: Pustaka Pelajar, 2002), p. 37-38

15 Richard C. Martin, Approaches, p. 2

${ }^{16}$ Tholhatul Choir, et al, Islam in Contemporary Readings, (Yogyakarta: Pustaka Pelajar, 2009), pp. 244
} 


\section{Nur Solikin}

studies fail to standardize itself as a discipline. ${ }^{17}$ However, Martin is still heartened that, even though religious studies have not been assessed as a discipline, it has run with a number of theoretical assumptions and methodological procedures that can be likened to studies in women's studies,AfricanAmerican studies, Jewish studies and various other studies in the field of Humanities., in which scholars of religious studies have tried to work on a data field by using various theories, methods and various religious databases from other disciplines inthe social sciences. $^{18}$

This can be done because - as Martin wrote, scholars of religious studies have roots in traditional scientific disciplines, namely, first, traditional humanities, second, theological disciplines, Bible studies and church history, third, social sciences such as anthropology. , linguistics and psychology, fourth, regional studies - especially eastern studies, such as the Middle East, East Asia, South and Southeast Asia. Such specialists, in the context of religious studies, identify theirteachings and writings on Islam as a historyof the science of religions. ${ }^{19}$

Evolution of the Study of History of Religion

In one of his writings, Amin Abdullah mentioned that the term history of religion is

17 Tholhatul Choir, et al, Islam, p. $242^{18}$ Richard C. Martin, Approaches, p. $2{ }^{19}$ Richard C. Martin, Approaches, P. 2 another name for the term science of religion (the Science of Religions) in the historicalempirical scientific tradition, in addition to other terms such as Comparative Religions, the Scientific Study of Religion. , some evencall it Religionwissenschaft, and Phenomenology of Religions. According to Amin Abdullah, this is because in the study of religion with the area of studying the phenomenon of human religious life in general, it is approached through variousscientific disciplines which are historical-empirical, not doctrinal-normative in nature,so that the science of religions is the history of religion (History of Religion). , Sociology of Religion, Psychology of Religion, Anthropology of Religion and so on. ${ }^{20}$

Likewise with Martin who mentions the terms History of Religion and Religious Studies as the two terms used in his edited book to show collectively some established approaches to religious studies, in other words, are used in order to better explain and understand religious data. from the Islamic tradition in the context of religious studies which generally requires a brief survey of developments in the historical discipline of religions during the past century. ${ }^{21}$

${ }^{20}$ M. Amin Abdullah, "The Relevance of the Study of Religions in the Third Millennium", in, Amin Abdullah, et al., Searching for Islam: Islamic Studies with Various Approaches, (Yogyakarta: Tiara Wacana Yogya, 2000), p. 1

${ }^{21}$ Richard C. Martin, Approaches, p. 5 
This discipline of study is an independent development after the study of history, anthropology, sociology, theologyand the study of the east have become independent scientific disciplines, and therefore, developments in these studies are quite influential in the workings of historians of religions which are then seen in subsequent developments. it is necessary to make a separation between religious studies from other disciplines. This is evident from the existence of religious studies that were studied in Europe during the second half of the 19th century which aimed to break awayfrom the faith of the church and theological faculties and of course had sparked conflict between church and scholarship. ${ }^{22}$ Subsequent developments occurred when in 1983 thefirst International Congress brought together historians of religion in Chicago. This iswhere Martin regrets the difficulty in regrowing the drive towards encyclopedic knowledge and scientific collaboration by involving experts in different areas ofexpertise. ${ }^{23}$

Among those who contributed to this were Friederich Muller and the founders of Religionswissenschaft. Muller is an expert in philology who adopted Darwin's theory of evolution as his approach to the study of

\footnotetext{
22 Tholhatul Choir, et al, Islam, p. 247

${ }^{23}$ Tholhatul Choir, et al, Islam, p. 247
}

culture and religion. Through this theory, Muller states that historical evolution has implications for the evolution of culture and religion from a simple form to a higher and more perfect form, therefore, if the assumption that has so far stated that Christianity is the highest form of religion there actually still leaves the evolutionary question of its origins. proposals and stages of development which can be seen in the study of other religions. Such a view of course implicitly acknowledges the theological assumptions about historicalprogress towards a natural religion which belongs to all human beings. $^{24}$

The next important change that brought a whole change of views was WorldWar I which was able to influence scholars to study religions. The notion of cultural evolution and the notion of human progress is subject to severe shocks, and as a result, there is an urgent need to find approaches that are capable of understanding the authentic expressions of other religions to speak without the influence of the personal values of scholars. In other words, an objective assessment of the role of religion in human life is needed so that a school in the Netherlands and Scandinavia hasemerged which is called the phenomenology

\footnotetext{
${ }^{24}$ Richard C. Martin, Approaches, p. 6
} 


\section{Nur Solikin}

of religion which is then attempted to be applied to religious manifestations through the pure descriptive method where researchers assess the value and truth of religious data positioned under an investigation that is deliberately suspended (epoche) and then an object is captured by itsessence (eidetic vision) which lies behind the religious phenomenon. Because of the importance of the suspension of judgment, the researcher then assumes that the empirical manifestation of religious phenomena hides the deepest numena or sacred reality that can only be grasped in essence.

An important method introduced by Martin in this case is Dilthey's das verstehen theory in an effort to understand the ideas, intentions and feelings of a person or society through empirical manifestations in culture. Verstehen presupposes that humans in all societies and historical environments experience meaningful lives and they express that meaning into visible patterns so that they can be analyzed and understood. ${ }^{25}$ Through this method, said Martin, the aim of understanding other people's religions for religious historians is more than just crosscultural knowledge but cross-cultural communication must also be instilled together with the theological goals of universal human understanding, and because

\footnotetext{
25 Tholhatul Choir, et al, Islam, p. 250
}

of this - continued Martin - international agencies for the historians of religions should achieve this goal by inviting adherents of religions to explain their faith in their own way. $^{26}$

This approach by Wilfred Cantwell Smith is called a personalist or dialogical approach which according to Smith - without neglecting the overall achievements in the study of the East and the history of religionsin the past - the object of scientific understanding is the belief that Muslim, Buddhist, Christian and Hindu individuals believe in the context of life. It is clear, where this faith is imperfectly exposed only in textual-normative materials from traditions such as Islam so that various readings of this material will fail to understand Muslim faithif it produces explanations and interpretations that are not in accordancewith what Muslims themselves mean. ${ }^{27}$ Even though Smith's approach on the one hand is considered to provide opportunities for the realization of dialogue in order to achieve a better understanding between adherents of one religion and followers of another religion, it is still under suspicion because many analytical programs require a distance between the researcher and the object understudy.

\footnotetext{
${ }^{26}$ Richard C. Martin, Approaches, p. 8-9

${ }^{27}$ Richard C. Martin, Approaches, P. 9
} 
Apart from the emergence of the above theories, since 1960 the history of religions at the University of North Americahas become increasingly aware of its identity as a scientific discipline. The birth of the structuralist analysis of myth by Levi-Straus, the study of religion as a system of cultural symbols by Clifford Geertz and the interpretation of aspects of ritual by Victor Turner helped to inspire serious discussionsamong religious historians. The achievements that have been shown by these anthropologists, although not explicitly recognized in the works of religious historians, according to Martin should be noted as achievements that have confirmed religion as a field of study. ${ }^{28}$

\section{Conclusions}

The mapping done by Richard C. Martin in his work, which comes from a collection of several articles, at least provides important information in terms of the methodology of the study of religion. This is what M. Amin Abdullah said, that Martin's work is full of methodological content directed at the author's efforts to bring and lift Islamic studies out of its historical- cultural traps and traps into the area of the mainstream of religious science vortex that

\footnotetext{
${ }^{28}$ Richard C. Martin, Approaches, P. 10
}

has developed since the century 19 with various methodological tools at its disposal. The hope is that it can bridge the methodological gap between Islamic Studies and Religionswissenschaft which is still being felt today.

Another thing that needs to be presented as a point of conclusion from this study is related to Martin's academic anxiety which was the background for the birth of his collection of writings. Regarding the background of this writing, it is motivated by the traditional position of Islamic studies at North American universities in eastern and regional study programs which are considered to be in strategic positions which is also a problem because it has created two sub-fields from different perspectives, and often even opens opportunities for the emergence of conflict between one another, namely, a theological point of view that maintains a normative understanding of other religions so that these religions must be judged by conventional Christian claims.

\section{References}

Abdullah, M. Amin, "Foreword" in, Richard C. Martin, Approaches to Islamic Studies in Religious Studies, trans. Zakiyudin Baidhawi (Surakarta: Muhammadiyah University Press, 2001) 


\section{Nur Solikin}

Abdullah, M. Amin, Islamic Studies in Higher Education: Integrative-Interconnective Approach (Yogyakarta: Pustaka Pelajar, 2006)

Abdullah, M. Amin, Religious Studies: Normativity or Historical (Yogyakarta: Pustaka Pelajar, 2011)

Abdullah, M. Amin, The philosophy of Kalam in the Postmodernism Era(Yogyakarta: Pustaka Pelajar, 2009)

Abdullah, M. Amin, "The Relevance of the Study of Religions in the Third Millennium", in, Amin Abdullah, et al., Looking for Islam: Islamic Studies with Various Approaches (Yogyakarta: Tiara Wacana Yogya, 2000)

Adam, Charles J., "Foreword", in, Richard C. Martin, Approaches to Islam in Religious Studies (Tucson: Arizona State University Press)

Choir, Tholhatul, et al, Islam inContemporary Readings (Yogyakarta: Pustaka Pelajar, 2009)

Ernst, Carl W. and Richard C. Martin, Rethinking Islamic Studies from Orientalism to Cosmopolitanism (Columbia, University of South Carolina Press, 2010)

Martin, Richard C., Approaches to Islam in Religious Studies (Tempe: Arizona State University Press)
Mudzhar, M. Atho, Approaches to Islamic Studies in Theory and Practice (Yogyakarta: Pustaka Pelajar, 2002), p.

Wandenburg, Jacques, "Islamic Studies in the Netherlands", in Nanji Azim (ed)., Mapof Islamic Orientalism Studies and New Directions of Islamic Studies in the West (Bantul: Fajar Pustaka Baru, 2003) http://cslr.law.emory.edu/people/person/na me/martin/. Accessed on, 01 September 2020 